\title{
PENERAPAN MODEL PEMBELAJARAN CORE (CONNECTING, ORGANIZING, REFLECTING AND EXTENDING) UNTUK MENINGKATKAN PRESTASI BELAJAR PESERTA DIDIK PADA POKOK BAHASAN KESETIMBANGAN KELARUTAN (KSP) DI KELAS XI IPA SMAN 4 PEKANBARU
}

\author{
Nurhafni*, Johni Azmi, Herdini Prodi Pendidikan Kimia FKIP Universitas Riau \\ Email : nurhafnihafni343@gmail.com
}

\begin{abstract}
The research about the CORE (Connecting, Organizing, Reflecting and Extending) model has been conducted in SMAN 4 Pekanbaru. The purpose of this research is to detemine wheterthe application of CORE learning can improve achievement and the influence of application of CORE learning model in class XI IPA SMAN 4 Pekanbaru on the subject solubility aquilibrium (Ksp). The type of this research is experimental research with experiment design randomized control group pretest-posttest. Sample of the research consisted of two classes, a class XI IPA 5 as an experimental class (implemented the CORE learning model) and class XI IPA 1 as the control class (without the CORE learning model). Test tecniques used as a tecnique in collecting research dats. T-test and coefficient determinasi was used as analysis technique. Based on the data analysis obtained $t>t$ table is $5,71>1,66$, meaning that the application of the CORE learning model can improve the student achievement on the subject solubility aquilibrium (Ksp) in class XI IPA SMA Negeri 4 Pekanbaru with the great influence of implementation of the CORE learning model on improving learning achievement is $31,178 \%$.
\end{abstract}

Key Words : Student Achievement, Learning Model, CORE, solubility aquilibrium (Ksp), SMAN 4 Pekanbaru.

\begin{abstract}
Abstrak
Penelitian tentang model pembelajaran CORE (Connecting, Organizing, Reflecting and Extending) telah dilaksanakan di SMAN 4 Pekanbaru. Tujuan dari penelitian ini yaitu untuk mengetahui apakah penerapan model pembelajaran CORE dapat meningkatkan prestasi belajar peserta didik dan besar pengaruh penerapan model pembelajaran CORE di kelas XI IPA pada pokok bahasan kesetimbangan kelarutan (Ksp). Jenis penelitian ini adalah penelitian eksperimen dengan desain penelitian randomized control group pretest-posttest. Sampel dari penelitian terdiri dari 2 kelas, kelas XI IPA 5 sebagai kelas eksperimen (diterapkan model pembelajaran CORE) dan kelas XI IPA 1 sebagai kelas kontrol (tanpa model pembelajaran CORE). Teknik test digunakan sebagai teknik dalam mengumpulkan data penelitian. Teknik analisis data yang digunakan adalah uji t dan koefisien determinasi (Kp). Berdasarkan hasil analisis data diperoleh

$t_{\text {hitung }}>t_{\text {tabel }}$ yaitu 5,71 >1,66, artinya penerapan model pembelajaran CORE dapat meningkatkan prestasi belajar peserta didik pada pokok bahasan kesetimbangan
\end{abstract}


kelarutan (Ksp) di kelas XI SMA Negeri 4 Pekanbaru dengan besar pengaruh penerapan model pembelajaran CORE terhadap peningkatan prestasi belajar peserta didik adalah $31,178 \%$.

Kata Kunci : Prestasi Belajar, Model Pembelajaran, CORE, kesetimbangan Kelarutan (Ksp), SMAN 4 Pekanbaru.

\section{PENDAHULUAN}

Pembelajaran memiliki peranan penting untuk meningkatkan kompetensi yang dimiliki peserta didik. Oemar Hamalik (2007) menjelaskan antara proses belajar dengan perubahan adalah dua gejala yang saling terkait yakni belajar sebagai proses dan perubahan sebagai bukti dari hasil yang diperoleh. Prestasi belajar adalah hasil yang dicapai peserta didik dalam bentuk angka-angka setelah diberikan suatu tes hasil belajar pada setiap akhir pertemuan, pertengahan semester dan akhir semester. Untuk meningkatkan prestasi belajar peserta didik, guru harus bisa memilih dan menerapkan cara pembelajaran yang tepat

Guru dalam proses pembelajaran berperan sebagai fasilitator, motivator, dan pembimbing untuk meningkatkan kemampuan peserta didik dalam mencapai tujuan pembelajaran (Slameto, 2010). Kimia merupakan salah satu mata pelajaran yang menuntut adanya pemahaman terhadap konsep dan keterampilan dalam perhitungan. Salah satu mata pelajaran kimia yang menuntut pemahaman konsep dan keterampilan perhitungan adalah kesetimbangan kelarutan (Ksp). Kesetimbangan kelarutan (Ksp) adalah salah satu pokok bahasan pada mata pelajaran kimia yang diajarkan di kelas XI semester II SMA. Untuk menguasai materi pada pokok bahasan kesetimbangan kelarutan (Ksp) diperlukan pemahaman terhadap konsep dan keterampilan berhitung dalam proses pembelajaran.

Hasil wawancara yang telah dilakukan dengan salah seorang guru kimia SMA Negeri 4 Pekanbaru bahwa nilai rata-rata ulangan peserta didik kelas XI tahun ajaran 2016/2017 pada pokok bahasan kesetimbangan kelarutan (Ksp) belum memenuhi Kriteria Ketuntasan Minimum (KKM) yaitu 81,19739 sementara Kriteria Ketuntasan Minimum (KKM) yang ditetapkan sekolah untuk pokok bahasan kesetimbangan kelarutan (Ksp) adalah 82. Hal ini disebabkan karena peserta didik kurang termotivasi untuk aktif sehingga tidak mampu memahami 
dan memaknai konsep pada pokok bahasan kesetimbangan kelarutan (Ksp) yang menyebabkan ketuntasan belajar menjadi rendah. Upaya yang dapat dilakukan untuk meningkatkan prestasi peserta didik yaitu mengemas suatu pembelajaran dengan model yang lebih menarik dan efisien yang membuat peserta didik berperan aktif (Happy Utami Ambarsih, dkk., 2016). Model pembelajaran tersebut yaitu CORE (Connecting, Organizing, Reflecting and Extending).

Model pembelajaran CORE adalah model pembelajaran yang menghubungkan konsep lama dengan konsep baru, mengorganisasikan sejumlah materi yang bervariasi, merefleksi segala sesuatu yang dipelajari peserta didik dan mengembangkan lingkungan belajar, sehingga dapat mengaktifkan peserta didik dalam membangun pengetahuannya sendiri. Hal ini sesuai dengan kelebihan dari model pembelajaran CORE yaitu, membuat peserta didik aktif dalam belajar, dapat melatih daya ingat peserta didik, melatih daya berfikir kritis peserta didik terhadap suatu masalah dan memberikan pengalaman belajar kepada peserta didik, karena peserta didik banyak berperan aktif dalam pembelajaran. Penelitian penerapan model pembelajaran CORE telah dilakukan oleh Hariyanto (2017) yang menyatakan bahwa terdapat perbedaan hasil belajar yang signifikan antara kelas eksperimen yang menggunakan model CORE dengan kelas kontrol tanpa model CORE dimana $t_{\text {hitung }}>t_{\text {table }}$ yaitu 5,4025 > 2,0150 (Wahyudi Siswanto dan Dewi Ariani, 2016).

Mengingat pentingnya penerapan model pembelajaran CORE terhadap prestasi belajar peserta didik, maka dilakukan penelitian dengan judul "Penerapan Model Pembelajaran Pembelajaran CORE (Connecting, Organizing, Reflecting and Extending) Untuk Meningkatkan Prestasi Belajar Peserta Didik Pada Pokok Bahasan Kesetimbangan Kelarutan (Ksp) Di Kelas XI IPA SMA Negeri 4 Pekanbaru". Penelitian ini bertujuan untuk mengetahu apakah penerapan model pembelajaran CORE dapat meningkatkan prestasi belajar peserta didik dan mengetahui besar pengaruh penerapan model pembelajaran CORE terhadap peningkatan prestasi belajar peserta didik pada pokok bahasan kelarutan kesetimbangan (Ksp) kelas XI IPA SMA Negeri 4 Pekanbaru. 


\section{METODE PENELITIAN}

Penelitian dilaksanakan di kelas XI SMAN 4 Pekanbaru semester genap, tahun ajaran 2017/2018. Waktu pengambilan data dilakukan pada bulan JanuariMei 2018. Populasi dalam penelitian ini adalah seluruh siswa kelas XI SMAN 4 Pekanbaru yang terdiri dari 4 kelas. Terlebih dahulu dilakukan uji homogenitas dari data yang telah terdistribusi normal pada seluruh populasi untuk memastikan seluruh kelas memiliki kemampuan yang sama. Kemudian dipilih dua kelas secara acak dengan cara diundi yang telah homogen untuk dijadikan sampel. Kelas XI IPA 5 sebagai kelas eksperimen (dengan model CORE) dan keas XI IPA 1 sebagai kelas kontrol (tanpa model CORE). Desain penelitian yang digunakan adalah Desain Randomized Control Group Pretest-Posttest yang dapat dilihat pada Tabel 1.

Tabel 1. Desain Penelitian

\begin{tabular}{cccc}
\hline Kelas & Pretest & Perlakuan & Posttest \\
\hline Eksperimen & T0 & X & T1 \\
\hline Kontrol & T0 & - & T1
\end{tabular}

Keterangan :

T0 = Data yang diperoleh dari nilai pretest, $\mathrm{X}=$ Perlakuan,

$\mathrm{T} 1$ = Data yang diperoleh dari nilai posttest

(Wina Sanjaya, 2013)

Teknik untuk mengumpulkan data dalam penelitian adalah teknik test. Data yang dikumpulkan diperoleh dari: (1). Data pra-analisis (nilai ulangan pokok bahasan sebelumnya yaitu larutan penyangga dan hidrolisis) digunakan untuk uji normalitas dan uji homogenitas. (2). Data penelitian dari nilai pretest dan posttest pada kelas eksperimen dan kelas kontrol (pokok bahasan kesetimbangan kelarutan) yang digunakan untuk uji hipotesis. Teknik analisis data yang digunakan pada penelitian adalah uji-t. Pengujian statistik dengan uji-t dapat dilakukan berdasarkan kriteria data yang berdistribusi normal dengan uji normalitas menggunakan uji Liliefors. Jika harga Lmaks<Ltabel, maka data berdistribusi normal. Harga Ltabel diperoleh dengan rumusan:

$L=\frac{0,886}{\sqrt{n}}$

(Agus Irianto, 2010) 
Setelah data berdistribusi normal, kemudian dilakukan uji homogenitas dengan menguji varians kedua sampel (homogen atau tidak) terlebih dahulu dengan rumus:

$$
\mathrm{F}=\frac{\text { varians terbesar }}{\text { varians terkecil }}
$$

Kemudian dilanjutkan dengan uji kesamaan rata-rata menggunakan uji-t dua pihak untuk mengetahui kehomogenan kedua sampel. Uji hipotesis yang digunakan merupakan uji-t pihak kanan dengan rumusan sebagai berikut:

$$
\mathrm{t}=\frac{\overline{x_{1}}-\overline{x_{2}}}{S_{g} \sqrt{\frac{1}{n_{1}}+\frac{1}{n_{2}}}}
$$

Sg merupakan standar deviasi gabungan yang dapat dihitung menggunakan rumus:

$$
S_{g}^{2}=\frac{\left(n_{1}-1\right) S_{1}^{2}+\left(n_{2}-1\right) S_{2}^{2}}{n_{1}+n_{2}-2}
$$

(Sudjana, 2005)

Untuk menentukan besar peningkatan prestasi belajar peserta didik melalui penerapan model pembelajaran CORE dilakukan dengan menentukan koefisien determinasi dengan rumus :

Keterangan :

$$
\mathrm{Kp}=\mathrm{r}^{2} \times 100 \% \text {, dimana } \mathrm{r}^{2}=\frac{t^{2}}{t^{2}+n-2}
$$

$\mathrm{Kp}=$ besarnya koefisien determinasi, $\mathrm{r}=$ koefisien korelasi $\mathrm{t}=$ lambang statistik untuk uji hipotesis, $\mathrm{n}=$ jumlah siswa

(Riduwan dan Sunarto, 2010)

\section{HASIL DAN PEMBAHASAN}

\section{Uji Pra-Analisis}

Hasil analisis uji normalitas dari data pra-analisis terlihat bahwa kedua sampel terdistribusi normal pada sampel 1 diperoleh Lmaks $<$ Ltabel yaitu 0,10 <0,15 dan sampel 2 diperoleh Lmaks $<$ Ltabel yaitu 0,13<0,15 dapat dilihat pada Tabel 2 sebagai berikut:

Tabel 2. Hasil Uji Normalitas Data Pra-Analisis

\begin{tabular}{cccccc}
\hline Kelas & $N$ & $\bar{x}$ & S & Lmaks & Ltabel \\
\hline Sampel 1 & 36 & 86,5278 & 8,18 & 0,10 & 0,15 \\
Sampel 2 & 36 & 86,8056 & 8,96 & 0,13 & 0,15 \\
\hline
\end{tabular}


Keterangan : $N=$ jumlah data pada sampel, ${ }^{\bar{x}}=$ nilai rata-rata sampel,

$\mathrm{S}=$ simpangan baku, $\mathrm{L}=$ lambang statistik menguji kenormalan.

Selanjutnya uji varians dilakukan sebagai syarat dari uji homogenitas, karena data yang diuji harus mempunyai varians yang sama. Hasil analisis uji homogenitas dapat dilihat pada Tabel 3 sebagai berikut:

Tabel 3. Hasil Uji Homogenitas Data Pra-Analisis

\begin{tabular}{cccccccc}
\hline Kelas & $N$ & $\sum X$ & $\bar{x}$ & Ftabel & Fhitung & ttabel & thitung \\
\hline Sampel 1 & 36 & 3115 & 86,5278 & & & & \\
Sampel 2 & 36 & 3125 & 86,8056 & 1,80 & 1,21 & 1,67 & 0,14 \\
\hline
\end{tabular}

Keterangan : $n$ = jumlah siswa, $\sum X=$ jumlah nilai soal materi prasyarat $\bar{X} \quad=$ nilai rata-rata soal materi prasyarat

Data pada Tabel 3, dapat dilihat perolehan nilai Fhitung $=1,21$ dan nilai Ftabel dari daftar distribusi $\mathrm{F}$ adalah 1,80. Jadi Fhitung $<$ Ftabel $\quad(1,21<1,80)$. Hal ini menunjukkan bahwa kedua kelompok sampel mempunyai varians yang sama atau homogen. Nilai thitung 0,14 dan nilai ttabel untuk uji kesamaan rata-rata dua pihak pada $\alpha=0,05$ dengan $\mathrm{dk}=70$ adalah 1,67. Nilai thitung terletak antara -ttabel dan ttabel $(-1,67<0,14<1,67)$, artinya rata-rata sampel 1 sama dengan rata-rata sampel 2 atau dapat dikatakan homogen.

\section{Uji Hipotesis}

Uji normalitas dilakukan pada nilai pretest dan posttest sebelum dilakukan uji hipotesis. Hasil analisis uji normalitas dapat dilihat pada Tabel 4 sebagai berikut:

Tabel 4. Hasil Uji Normalitas Data Pretest Dan Posttest

\begin{tabular}{ccccccc}
\hline Data & Kelas & $N$ & $\bar{x}$ & S & Lmaks & Ltabel \\
\hline \multirow{2}{*}{ Pretest } & Eksperimen & 36 & 26,2222 & 8,36 & 0,13 & 0,15 \\
& Kontrol & 36 & 25,4444 & 6,43 & 0,13 & 0,15 \\
\multirow{2}{*}{ Posttest } & Eksperimen & 36 & 88,4444 & 5,04 & 0,13 & 0,15 \\
& Kontrol & 36 & 85,6667 & 4,52 & 0,11 & 0,15 \\
\hline
\end{tabular}

Keterangan: $\mathrm{S} \quad=$ standar deviasi nilai posttest

Peningkatan prestasi belajar diperoleh setelah dilakukan perhitungan selisih nilai pretest-posttest yang telah diuji menggunakan statistik uji-t. Hasil analisis uji 
hipotesis dapat dilihat pada Tabel 5 sebagai berikut:

Tabel 5. Hasil Uji Hipotesis

\begin{tabular}{ccccccc}
\hline Kelas & $N$ & $\sum X$ & $\bar{x}$ & $S_{\text {gab }}$ & tabel & thitung \\
\hline Ekperimen & 36 & 2240 & 62,2222 & \multirow{2}{*}{3,55} & \multirow{2}{*}{1,66} & \multirow{2}{*}{5,71} \\
Kontrol & 36 & 2068 & 57,4444 & 3,50 &
\end{tabular}

Keterangan : $\sum X=$ jumlah nilai selisih pretest dan posttest,

$\overline{\boldsymbol{x}}=$ nilai rata-rata selisih pretest dan posttet

\section{Menentukan Besar Pengaruh Penerapan Terhadap Prestasi Belajar}

Besar pengaruh penerapan model pembelajaran CORE terhadap peningkatan prestasi belajar peserta didik pada pokok kesetimbangan kelarutan (Ksp) di kelas XI IPA SMA Negeri 4 Pekanbaru adalah 31,178\%.

\section{Pembahasan}

Peningkatan prestasi belajar peserta didik pada kelas eksperimen disebabkan karena dengan penerapan model pembelajaran CORE meningkatkan aktifitas peserta didik selama proses pembelajaran. Model pembelajaran CORE menuntut semua peserta didik untuk aktif sehingga tidak hanya didominasi oleh peserta didik yang sama. Model pembelajaran CORE juga melatih daya ingat peserta didik dan memberikan pengalaman belajar kepada peserta didik sehingga pembelajaran menjadi bermakna. Aktifitas peserta didik selama proses pembelajaran akan berdampak langsung terhadap prestasi belajar. Hal ini sesuai dengan pendapat Dimyati dan Mudjiono (2006) yang mengatakan bahwa prestasi belajar tidak dapat dipisahkan dengan kegiatan belajar karena kegiatan belajar merupakan proses sedangkan prestasi belajar merupakan hasil dari proses belajar. Aktifitas peserta didik selama proses pembelajaran dapat dilihat pada setiap tahap model pembelajaran CORE. Tahap pertama yaitu tahap connecting yang merupakan tahap guru mengkoneksikan pengetahuan awal yang dimiliki peserta didik dengan membimbing jalan pikiran peserta didik untuk menhubungkan konsep lama dengan konsep baru. Pada tahap ini guru menghubungkan pengetahuan awal siswa dengan pengetahuan yang akan dipelajari melalui beberapa cara, salah satunya adalah dengan memberikan pertanyaan yang berhubungan dengan pokok bahasan sebelumnya kemudian mengaitkan dengan 
pokok bahasan yang akan dipelajari sehingga dapat membangun pengetahuan awal peserta didik. Contohnya pada pertemuan pertama guru memberikan dua contoh persamaan reaksi yaitu $\mathrm{NaOH}_{(\mathrm{aq})} \quad \mathrm{Na}^{+}{ }_{(\mathrm{aq})}+\mathrm{OH}_{(\mathrm{aq}}^{-}$an $\mathrm{BOH}_{(\mathrm{aq})}$ $\mathrm{B}^{+}{ }_{(\mathrm{aq})}+\mathrm{OH}_{(\mathrm{aq})}^{-}$kemudian guru mengajukan pertanyaan "Siapa yang masih ingat manakah yang merupakan persamaan reaksi kesetimbangan? Jadi, apakah yang dimaksud dengan kesetimbangan?”. Dari contoh ini guru mencoba mengaitkan pengetahuan yang sudah dimiliki siswa mengenai kesetimbangan, materi kesetimbangan adalah salah satu materi prasyarat yang perlu dikuasai peserta didik sebelum mempelajari materi kelarutan dan hasil kali kelarutan. Hal ini sesuai dengan pendapat Ratna Wilis Dahar (2006) mengungkapkan bahwa faktor yang paling mempengaruhi belajar adalah pengetahuan awal peserta didik sehingga pelajaran yang baru dapat diadaptasi dengan pengetahuan yang telah dimiliki. Tahapan connecting ini juga menjadi penting karena pada tahapan ini berkaitan dengan pengetahuan awal peserta didik yang berpengaruh langsung dengan kemampuan peserta didik dalam menerima materi yang baru, hal ini sesuai dengan pendapat Trianto (2014) yang mengatakan jika kemampuan awal yang dimiliki oleh seseorang tinggi maka akan mudah menerima materi baru yang akan pelajari.

Tahap kedua yaitu tahap organizing merupakan kegiatan peserta didik untuk dapat mengorganisasikan informasi-informasi yang diperoleh. Dalam membantu peserta didik untuk dapat mengorganisasikan informasi-informasi berupa konsep. Guru memfasilitasi peserta didik dengan memberikan lembar organizing. Lembar organizing berisi pertanyaan-pertanyaan yang bertujuan agar peserta didik dapat menemukan dan dapat mengorganisasikan konsep atau informasi baru dengan baik. Peserta didik diminta untuk mengerjakan lembar organizing secara individu, dengan cara ini konsep yang di dapat akan melekat lama diingatan peserta didik. Hal ini dikarenakan pertanyaan-pertanyaan yang ada di dalam lembar organizing saling berkaitan sehingga dengan menjawab lembar organizing peserta didik lebih dapat mengorganisasikan konsep yang didapat dalam proses pembelajaran. Contohnya pada pertemuan pertama di dalam lembar organizing terdapat 10 pertanyaan yang saling berkaitan. Dalam lembar organizing guru juga 
menyajikan gambar percobaan. Contohnya didalam lembar organizing dijelaskan bahwa terdapat tiga percobaan.

Percobaan pertama menjelaskan bahwa ketika dimasukkan 20 gram $\mathrm{NaCl}$ ke dalam $100 \mathrm{~mL}$ air dihasilkan larutan $\mathrm{NaCl}$ namun kita belum mengetahui apakah larutan $\mathrm{NaCl}$ yang dihasilkan merupakan larutan tidak jenuh, larutan jenuh atau larutan lewat jenuh. Kemudian pada percobaan kedua dimasukkan 40 gram $\mathrm{NaCl}$ kedalam $100 \mathrm{~mL}$ air dihasilkan larutan lewat jenuh $\mathrm{NaCl}$ ditandai dengan adanya endapan pada larutan yang dihasilkan. Larutan yang terdapat endapan tersebut lalu disaring, didapat kan larutan jenuh $\mathrm{NaCl}$ dan 4 gram $\mathrm{NaCl}$ yang tidak larut, artinya hanya 36 gram maksimum $\mathrm{NaCl}$ yang dapat larut didalam $100 \mathrm{~mL}$ air. Selanjutnya percobaan ketiga, dimasukkan 20 gram $\mathrm{AgCl}$ kedalam $100 \mathrm{~mL}$ air dihasilkan larutan lewat jenuh yang ditandai dengan adanya endapan pada larutan tersebut. Larutan lewat jenuh kemudian disaring sehingga dihasilkan larutan jenuh $\mathrm{AgCl}$ dan 19,998 gram $\mathrm{AgCl}$ yang tidak larut, artinya hanya 0,002 gram maksimum $\mathrm{AgCl}$ yang dapat larut dalam $100 \mathrm{~mL}$ air.

Peserta didik dapat memahami gambar percobaan pada lembar organizing tersebut ditandai ketika peserta didik mampu menjawab pertanyaan nomor 1 sampai 10 . Pertanyaan yang saling berkaitan seperti di atas sangat membantu peserta didik dalam memahami dan mengorganisasikan konsep dalam proses pembelajaran. Hal ini sesuai menurut pendapat Andi Prastowo (2013) yang mengatakan bahwa model CORE termasuk model pembelajaran yang berlandaskan pada teori konstruktivisme dimana peserta didik harus dapat mengkonstruksikan pengetahuannya sendiri melalui interaksi diri dengan objek, fenomena, pengalaman dan lingkungannya sehingga, proses pembelajaran menjadi lebih bermakna dan dapat mempengaruhi perkembangan pengetahuan serta kemampuan berfikir pesera didik.

Tahap ketiga yaitu tahap reflecting. Pada tahap reflecting peserta didik diminta untuk merefleksi jawaban lembar organizing dengan mengisi lembar reflecting di dalam kelompok sesuai dengan perintah yang terdapat di dalam lembar reflecting. Di dalam kelompok peserta didik melakukan diskusi mengenai jawaban lembar organizing mereka. Dalam diskusi ini, salah seorang anggota kelompok 
mempresentasikan jawaban lembar organizing-nya, sementara anggota kelompok yang lain menyimak, kemudian jika ada jawaban yang berbeda peserta didik diminta untuk berdiskusi dan dapat menyimpulkan jawaban yang benar. Pada dasarnya peserta didik dituntut untuk mampu mengumpulkan data berupa konsep pembelajaran yang benar. Hal ini bertujuan agar setiap kelompok mempunyai konsep, informasi serta teori yang akan berguna dalam menjawab LKPD. Hasil dari diskusi ditulis dalam lembar reflecting yang telah disediakan oleh guru. Proses diskusi seperti ini dapat membuat peserta didik lebih aktif dalam menanggapi atau bertanya jika tidak mengerti dengan konsep yang sedang dipelajari, melatih rasa tanggung jawab dan toleransi dalam menghargai pendapat sesasama teman kelompok. Hal ini sesuai dengan pendapat Suharsimi Arikunto (2002) bahwa adakalanya seorang peserta didik lebih mudah merima keterangan yang diberikan oleh teman sebangku atau teman yang lain karena tidak ada rasa enggan atau malu untuk bertanya.

Kegiatan diskusi kelompok dilanjutkan dengan mengerjakan LKPD pada tahap Ekstending. Tahap ekstending ini memberikan kesempatan kepada peserta didik untuk mensintesis pengetahuan mereka dan mengaplikasikan pengetahuan tersebut dalam suasana baru yaitu dengan mengerjakan LKPD. Hal ini sesuai dengan pendapat Suyatno (2009) yaitu tahap ekstending merupakan tahap dimana peserta didik dapat memperluas pengetahuan yang sudah diperoleh selama proses pembelajaran berlangsung.

Pemahaman peserta didik terhadap pokok bahasan kesetimbangan kelarutan (Ksp) pada setiap pertemuan dapat dilihat dari nilai evaluasi dan nilai LKPD. Rata-rata nilai LKPD dan nilai evaluasi peserta didik di kelas eksperimen cenderung lebih tinggi dari pada nilai LKPD dan nilai evaluasi peserta didik di kelas control.

Aspek afektif dan aktivitas peserta didik pada pokok bahasan kesetimbangan kelarutan (Ksp) dengan menerapkan model pembelajaran CORE memiliki hubungan positif terhadap prestasi belajar peserta didik. Peserta didik pada kelas eksperimen yang belajar dengan menerapkan model CORE rata-rata memiliki nilai sikap dan aktifitas yang lebih tinggi dibandingkan dengan peserta didik di kelas kontrol tanpa penerapan model pembelajaran CORE. Hal ini sesuai dengan 
pendapat Saifuddin Azwar (2005), bahwa individu dengan sikapnya akan berusaha memaksimalkan hal-hal yang diinginkannya. Dalam kaitannya dengan ini, peserta didik memiliki keinginan untuk mampu menjawab setiap pertanyaan dalam lembar organizing yang diberikan ketika berada pada tahap organizing karena peserta didik akan mempresentasikan jawaban tersebut didalam kelompok pada tahap reflecting secara bergantian setiap pertemuan yang telah ditentukan sebelumnya, sehingga peserta didik akan mengusahakan secara optimal dengan belajar agar dapat menjawab lembar organizing dan mempresentasikan dengan benar didalam kelompok masing-masing.

Kendala yang dihadapi pada saat penelitian yaitu pada pertemuan pertama penyusunan tempat duduk yang memerlukan waktu lama dan penataan ruangan kelas kurang rapi. Namun pada pertemuan berikutnya peserta didik sudah langsung menyusun tempat duduknya secara teratur dan menata ruang kelas dengan rapi.

\section{KESIMPULAN}

Berdasarkan hasil penelitian dan pembahasan dapat disimpulkan bahwa: Penerapan model pembelajaran CORE (Connecting, Organizing, Reflecting and Extending) dapat meningkatkan prestasi belajar peserta didik pada pokok bahasan kesetimbangan kelarutan (Ksp) di kelas XI SMAN 4 Pekanbaru melalui analisis uji t pihak kanan, hasil uji hipotesis $\mathrm{t}_{\text {hitung }}=5,71$ dan nilai $\mathrm{t}_{\text {tabel }}$ pada $\alpha=0,05$ dengan $\mathrm{dk}=65$ adalah 1,66 artinya $\mathrm{t}_{\text {hitung }}$ lebih besar daripada $\mathrm{t}_{\text {tabel }}$ yaitu 5,71 > 1,66 sehingga $H_{1}$ diterima dengan besarnya pengaruh penerapan model pembelajaran CORE terhadap peningkatan prestasi belajar peserta didik pada pokok kesetimbangan kelarutan (Ksp) di kelas XI IPA SMA Negeri 4 Pekanbaru adalah $31,178 \%$. 


\section{DAFTAR PUSTAKA}

Agus Irianto, 2010, Statistik Konsep Dasar dan Aplikasi, Kencana Prenada Media Group, Jakarta

Andi Prastowo,2013, Panduan Kreatif Membuat Bahan Ajar Inovatif, Diva Press, Yogyakarta

Dimyati dan Mudjiono, 2006, Belajar dan Pembelajaran, PT Rineka Cipta, Jakarta

Happy Utami Ambarsih, Alifia Kurnia, Dwi Nugroho Andriyanto, Kiki Dya Prastiwi dan Meritania Yusman, 2016, Meningkatkan Kemampuan Berfikir Kritis Siswa pada Materi Gaya Gesek Melalui Model Pembelajaran CORE (Connecting, Organizing, Reflecting, Extending), Prosidding Seminar Nasional Quantum, ISSN: 2477-1511, Pendidikan Fisika FKIP Universitas Sebelas Maret, Surakarta

Hariyanto, 2017, Penerapan Model CORE Dalam Pembelajaran Matematika Untuk Meningkatkan Kemampuan Komunikasi Matematika Siswa, Jurnal Gammath, 2 (1) : 11 - 19

Oemar Hamalik, 2009, Strategi Belajar Mengajar, Pustaka Martiana, Bandung

Riduwan dan Sunarto, 2010, Pengantar Statistika, Alfabeta, Bandung Ridwan

Abdullah Sani, 2016, Inovasi Pembelajaran, Bumi Aksara, Jakarta

Slameto,2010, Belajar dan Faktor yang Mempengaruhinya, Rineka Cipta, Jakarta

Sudjana, 2005, Metode Statistika, Tarsito, Bandung

Suharsimi Arikunto, 2002, Pengelolaan Kelas dan Siswa, Rajawali, Jakarta

Suyatno, 2009, Menjelajah Pembelajaran Inovatif, Mas Media Buana Pustaka, Sidoarjo

Trianto,2014, Mendesain Model Pembelajaran Inovatif Progresif dan Kontekstual, Kencana, Jakarta

Wahyudi Siswanto dan Dewi Ariani, 2016, Model Pembelajaran Menulis Cerita, Refika Aditama, Bandung,

Wina Sanjaya, 2013, Penelitian Pendidikan Jenis, Metode Dan Prosedur, Kencana Prenada Media Group, Jakarta 